\title{
PENGAMBILAN KEPUTUSAN WAKTU PANEN PADA USAHA PEMBESARAN LOBSTER DI PULAU LOMBOK PROVINSI NTB
}

\author{
Deden Kurniawan $^{* 1}$, Rina Oktaviani**), Bunasor Sanim ${ }^{* * *}$, dan Heny K. Daryanto ${ }^{* * * *}$ \\ *) Badan Koordinasi dan Kegiatan Kesejahteraan Sosial \\ Jl. Salemba Tengah No. 51, Jakarta Pusat 10440 \\ **) Departemen Ilmu Ekonomi, Fakultas Ekonomi dan Manajemen, Institut Pertanian Bogor \\ Jl. Agatis Kampus IPB Darmaga, Bogor 16680 \\ ${ }^{* * *}$ Sekolah Bisnis, Institut Pertanian Bogor \\ Jl. Raya Pajajaran, Bogor 16151
}

\begin{abstract}
Lobsters represent as a valuable commodity to be determined by their length and weight. In Indonesia, the minimum legal size of lobster is $7 \mathrm{~cm}$ of carapace length and 200 grams of weight, and this is stipulated on regulation of Ministry of Marine Affairs and Fisheries No.1/2015. Instead of behaving in accordance with the rule, farmers still harvest lobsters as soon as they are of marketable size to reduce the risk of mortality and to generate income instantly. This paper develops a structural equation model partially least square (SEM PLS) to analyze decision making process to harvest lobster in Indonesia. The study established by structural equation modeling partially least square shows that the decision making to harvest lobster is driven by patron-client relationship, time constraint, and working complexity.
\end{abstract}

Keywords: lobster growing activities, decision to harvest, Lombok, SEM PLS

\begin{abstract}
ABSTRAK
Lobster sebagai komoditas yang berharga ditentukan oleh ukuran panjang dan berat. Di Indonesia, berdasarkan Peraturan Menteri Kelautan dan Perikanan No.1 / 2015, ukuran minimal lobster adalah memiliki panjang karapas $7 \mathrm{~cm}$ dan berat 200 gram. Pelaku usaha pembesaran lobster justru tidak mentaati aturan yang ada, ukuran lobster yang dipanen justru ditentukan oleh permintaan pasar yang dilakukan untuk mengurangi risiko kematian lobster dan mempercepat waktu dalam memperoleh penghsilan. Penelitian ini dilakukan untuk melakukan analisis keputusan waktu panen lobster di Indonesia. Metode yang digunakan adalah model persamaan struktural sebagian least square (SEM PLS). Hasil studi menunjukkan bahwa keputusan untuk memanen lobster ditentukan oleh hubungan patron dengan klien, keterbatasan waktu, dan kompleksitas pekerjaan.
\end{abstract}

Kata kunci: kegiatan pembesaran lobster, keputusan waktu panen, Lombok, SEM PLS

\footnotetext{
${ }^{1}$ Alamat Korespondensi:

Email: dedenkurniawan@yahoo.com
}

\section{PENDAHULUAN}

Usaha kelautan dan perikanan Indonesia dapat menggerakkan perekonomian nasional karena memiliki potensi sebesar US\$82 miliar per tahun. Data menunjukkan bahwa pada tahun 2014, terjadi krisis perekonomian dunia, perubahan kondisi iklim, dan maraknya Illegal Unreported and Unregulated Fishing (IUUF) ternyata sektor perikanan tumbuh sebesar 6,96\% (sektor pertanian 3,3\% dan PDB Nasional 5,1\%) dengan rata-rata pertumbuhan selama tahun 2009-2014 sebesar 6,25\% (Kementerian Kelautan dan Perikanan Republik Indonesia, 2015). Namun demikian, masih terdapat subsektor yang memiliki nilai ekonomi tinggi tetapi belum dikembangkan secara maksimal, yaitu lobster (Panulirus spp). Berdasarkan data Kementerian Kelautan dan Perikanan Republik Indonesia (2015) volume ekspor lobster tahun 2014 dibandingkan 2013 justru mengalami penurunan 1,67\% menjadi $0,92 \%$ (terjadi penurunan sebesar $44,78 \%$ atau senilai 27.104.000 Dolar Amerika Serikat)(Tabel 1). 
Tabel 1. Nilai ekspor per jenis produk perikanan dalam ribuan Dollar Amerika Serikat

\begin{tabular}{lrrrrr}
\hline \multicolumn{1}{c}{ Jenis } & \multicolumn{1}{c}{2010} & \multicolumn{1}{c}{20112} & \multicolumn{1}{c}{2013} & \multicolumn{1}{c}{2014} \\
\hline Udang & 1.036 .735 & 1.285 .895 & 1.253 .473 & 1.614 .143 & 2.092 .442 \\
Tuna, Tongkol, Cakalang & 388.257 & 498.635 & 749.992 & 764.791 & 692.607 \\
Kepiting/rajungan & 208.424 & 262.321 & 329.724 & 359.304 & 414.372 \\
Rumput laut & 114.348 & 133.514 & 177.922 & 209.701 & 279.337 \\
Cumi, sotong, gurita & 81.914 & 150.019 & 167.685 & 145.166 & 154.914 \\
Lobster & 13.010 & 16.458 & 50.675 & 69.943 & 42.839 \\
\hline
\end{tabular}

Sumber: Kementerian Kelautan dan Perikanan Republik Indonesia, 2015

Setidaknya terdapat empat alasan teknis untuk mengembangkanusahapembesaran lobsterdiIndonesia. Pertama, laut Indonesia memiliki banyak spesies benih lobster (menur) bernilai ekonomis tinggi dengan daerah penyebaran meliputi pantai barat Sumatera, selatan (Jawa, Bali dan Nusa Tenggara, Paparan Sunda, Selat Malaka), sebelah timur (Kalimantan), utara (Sulawaesi, Maluku, dan Papua) (Kanna 2006). Kedua, ketersediaan menur alami dalam jumlah besar. Dengan hasil pendugaan fekunditas lobster per ekor yang jumlahnya akan meningkat secara linier dengan panjang karapas (carapace length): $\mathrm{P}$. homarus (CL 80-95 mm) berkisar 28.000-96.000, P. versicolor (CL 85-100 mm) berkisar 16.500-71.000 butir, P. ornatus (CL 85-100 mm) berkisar 47.000-87.000 butir, P. Penicillatus (CL 65-100 mm) berkisar 31.000152.000 butir, dan P. Longiceps (CL 85-95 mm) berkisar 47.000-140.000 butir (Junaidi et al. 2010). Menur dapat dengan mudah dengan menggunakan alat tangkap sederhana yang dikenal dengan nama Pocong. Penangkapan anakan lobster berukuran $0,5-1,5 \mathrm{~cm}$ di Indonesia dapat dilakukan setiap hari sepanjang tahun, kecuali saat bulan purnama. Ketiga, lahan untuk usaha pembesaran lobster masih tersedia dengan jumlah yang besar. Data menunjukkan bahwa pemanfaatan lahan untuk budidaya perikanan air laut baru seluas 413.862 ha $(4,95 \%)$ lahan yang tersedia seluas 8.363.501 ha (Kementerian Kelautan dan Perikanan Republik Indonesia, 2015). Keempat, usaha pembesaran lobster dapat menjadi pengungkit bagi masyarakat pesisir karena merupakan usaha perikanan yang dimensi ganda. Cakupan dari usaha pembesaran lobster meliputi kegiatan perikanan tangkap dan perikanan budidaya. Perikanan tangkap karena benih lobster diperoleh secara alami, dan perikanan budidaya karena pembesaran lobster meliputi kegiatan budidaya yang meliputi kegiatan pembesaran dan panen.

Potensi sumber daya lobster tersebut justru tidak dapat dimanfaatkan akibat diterbitkannya Peraturan Menteri
Kelautan dan Perikanan Republik Indonesia Nomor 1/Permen-KP/2015 tentang Penangkapan Lobster (Panulirus spp.), Kepiting (Scylla spp.), dan Rajungan (Portunus pelagicus spp.) (Permen No.1/2015) yang berlaku sejak tanggal 6 Januari 2015. Walaupun Permen No.1/2015 sejalan dengan Acheson (2003) dan Sundelof et al. (2014) untuk konservasi lobster, tetapi dirasakan berat karena lobster (Panulirus spp.) yang boleh ditangkap dan diperjualbelikan harus memiliki ukuran panjang karapas $8 \mathrm{~cm}$ dengan berat minimal 200 gram. Pembatasan ini menyebabkan respon yang negatif dari industri lobster baik usaha penangkapan maupun usaha pembesaran. Bentuk dari ketidakpatuhan tersebut adalah meliputi terjadinya penurunan kuantum baik jumlah maupun nilai lobster pada perdagangan lokal dan ekspor, terjadi protes dari pelaku usaha lobster, ditinggalkannya usaha budidaya lobster, dan maraknya penyelundupan menur dan lobster bertelur ke luar negeri.

Bagi pelaku usaha pembesaran lobster, berlakunya Permen No.1/2015 berdampak negatif. Pertama, menyebabkan terhentinya pasokan menur karena secara hukum pengambilan menur dari alam menjadi suatu tindakan yang melawan hukum karena selama ini belum ada menur yang diperoleh dari kegiatan budidaya. Kedua, jika usaha pembesaran lobster tetap dilaksanakan dengan adanya pembatasan ukuran lobster yang boleh dijual akan berimbas pada waktu pembesaran yang semakin lama, yaitu berkisar 12 bulan untuk mencapai berat 300 gram atau berkisar 3-4 tahun untuk mencapai berat $1 \mathrm{~kg}$, lamanya waktu pembesaran ini adalah konsekuensi logis akibat dari sifat alamiah lobster yang tumbuh secara exoskeleton. Ketiga, lobster yang dibesarkan secara budidaya juga dihadapkan pada adanya variasi fisik, mutu, maupun kematian lobster yang diakibatkan oleh faktor alam berupa perubahan iklim. Keempat, selain keharusan untuk dapat mengatasi persoalan efisiensi dan keberlanjutan usaha pembesaran, para pelaku usaha pembesaran lobster 
juga dihadapkan pada kondisi yang semakin kompleks akibat adanya keharusan untuk memenuhi kebutuhan hidup sehari-harinya.

Analisis penentuan waktu panen tersebut dibutuhkan mengingat keputusan waktu panen adalah titik kritis dalam kegiatan usaha pertanian (William dan Malcolm, 2012). Demikian pula halnya dengan usaha pembesaran lobster, keputusan penentuan waktu panen selain dihadapkan pada adanya aturan hukum dalam Permen No.1/2015, para pelaku usaha pembesaran lobster akan selalu dihadapkan pada suatu kondisi yang tidak pasti dalam mengelola risiko yang bersifat dinamis, dan multi dimensi sebagai pengaruh langsung dari adanya ketidakpastian pada usaha perikanan dari lobster itu sendiri sebagai suatu sifat alamiah dari lobster itu sendiri, dan faktor manusia selaku pelaku usaha pembesaran lobster yang dihadapkan pada berbagai persoalan hidupnya.

Dengan memahami pengambilan keputusan waktu panen yang dilakukan oleh para pelaku usaha pembesaran lobster akan membantu dalam mencapai keberhasilan pelaksanaan Permen No.1/2015 dan peningkatan kesejahteraan masyarakat pesisir. Hal ini sejalan dengan Hilborn (2007) memahami perilaku pelaku usaha di sektor perikanan adalah kunci bagi suksesnya manajemen perikanan. Dalam hal ini, usaha pembesaran lobster akan identik dengan kebutuhan dan pola hidup masyarakat pesisir, terutama nelayan dan pembudidaya perikanan yang memiliki karakteristik khusus.

Berdasarkan kondisi tersebut, tujuan dari penelitian ini adalah melakukan analisis faktor-faktor yang menjadi dasar dalam pengambilan keputusan dari para pelaku usaha pembesaran lobster untuk menentukan waktu panen yang optimal.

\section{METODE PENELITIAN}

Penelitian dilakukan di Kabupaten Lombok Timur, Kecamatan Jero Waru, Desa Jerowaru: Dusun Telong Elong, dan Desa Pare Mas: Dusun Gili Ree, Dusun Gili Belek, dan Dusun Ujung Batu Putee pada Oktober 2015- April 2016. Alasan pemilihan lokasi penelitian adalah usaha budidaya pembesaran lobster dengan jumlah konsentrasi terbesar berada di Pulau Lombok NTB (Petersen et al. 2012) dan tingginya angka penyelundupan menur dan lobster bertelur.
Pengumpulan data menggunakan teknik sampling snowball, dilakukan karena pada saat awal penelitian ini dimulai pada bulan September 2015 usaha pembesaran lobster ditinggalkan oleh pelaku usahanya akibat dari berlakunya Permen No.1/2015. Pengumpulan data dilakukan dengan dua kali penelitian lapangan. Penelitian lapangan pertama dilakukan untuk mengetahui lokasi usaha pembesaran lobster yang masih berjalan, dengan jumlah responden yang diperoleh sebanyak 97 orang. Penelitian lapangan kedua, recall data hanya diperoleh dari 96 orang. Penelitian lapangan kedua dilakukan untuk mengetahui apakah panen pada Januari 2016 telah dilakukan sesuai dengan ketentuan dalam Permen No.1/2015, dan apakah persiapan waktu panen pada Juni 2016 akan dilakukan berpedoman pada Permen No.1/2015.

Pengambilan keputusan dalam penentuan waktu panen lobster adalah manifestasi dari ide individu dan harapan untuk mendapatkan suatu hasil yang baik maka penelitian ini akan berangkat dari premis bahwa individu pelaku usaha pembesaran lobster dalam pengambilan keputusan memiliki keterbatasan dalam memperoleh seluruh informasi yang dibutuhkan untuk memperhitungkan seluruh konsekwensi yang diakibatkan oleh keputusan yang diambil. Mengingat sifat alamiah individu yang terbatas tersebut maka teori rasionalitas terbatas (bounded rationality theory) yang dikemukakan oleh Simon (1959) menjadi grand theory design bagi penelitian ini dimana dalam pengambilan keputusan, rasionalitas individu dibatasi oleh informasi yang dimiliki, keterbatasan kognitif, dan ketersedian waktu. Kerangka pemikiran penelitian selengkapnya pada Gambar 1.

Dengan rasionalitas terbatas, pembuat keputusan yang tidak mampu memperoleh informasi yang tidak sempurna akan melakukan framing berupa tindakan mengedit dan memilih berupa proses yang dipandu oleh asumsi-asumsi berdasarkan pada stereotype dan tipologi yang menyederhanakan informasi apakah yang dipertimbangkan dan yang tidak dipertimbangkan (Chong dan Druckman, 2007). Konsep bounded rationality theory menjadi menarik untuk digunakan karena walaupun memiliki keterbatasan berupa keterbatasan dalam diri individu itu sendiri. Namun, disisi lain individu memiliki pengalaman dan adanya unsur ketidakpastian yang selalu dihadapinya, individu yang memberikan dasar pengetahuan bagi individu atas berbagai mekanisme yang dapat dipilih dalam memperoleh alternatif rasional yang akan diambil. 


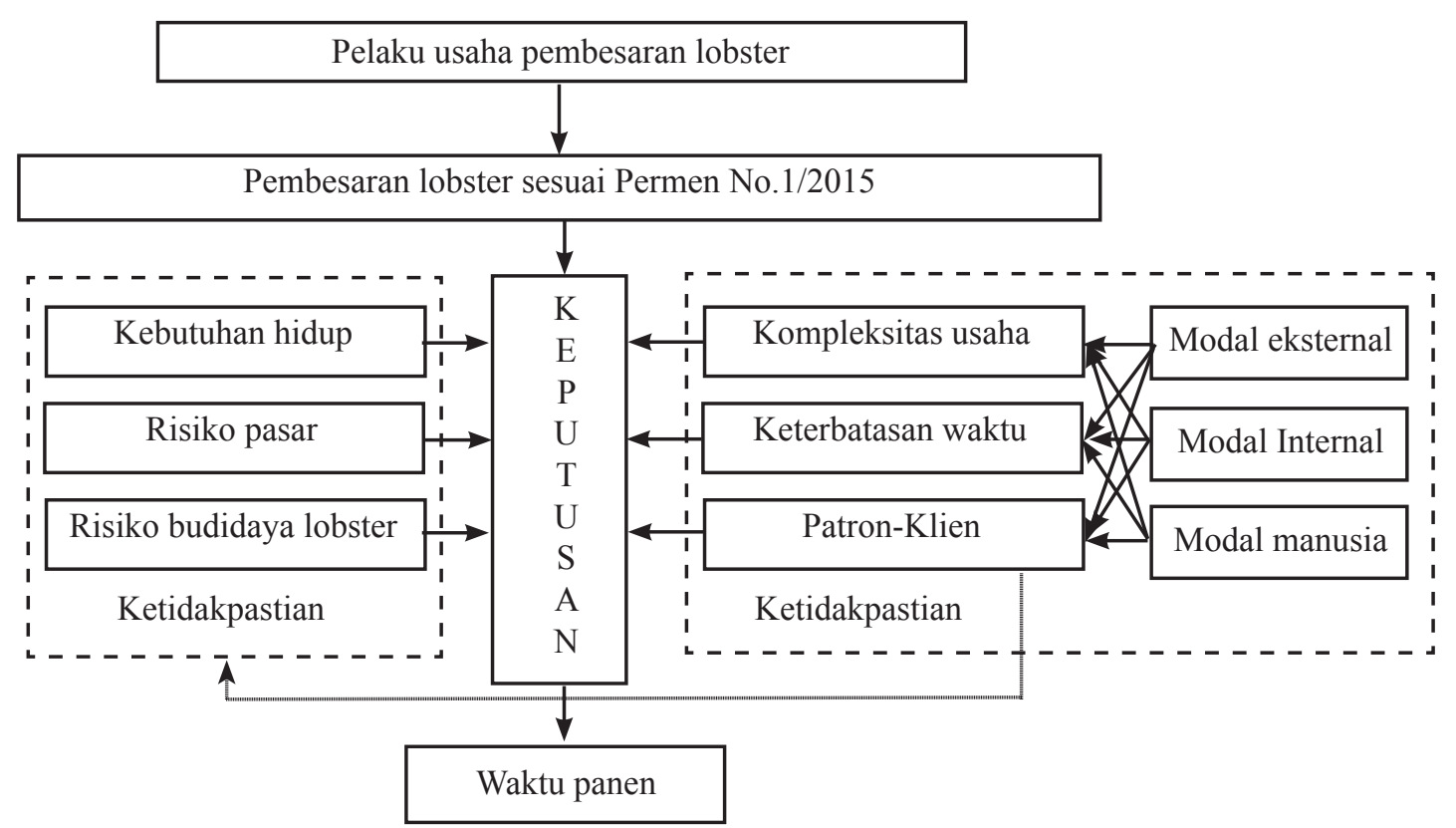

Gambar 1. Kerangka pemikiran penelitian

Pengambilan keputusan untuk menentukan waktu panen oleh pelaku usaha pembesaran lobster dianalisis dengan menggunakan Structural Equation Modeling (SEM) Partial Least Squares (PLS) untuk merumuskan strategi pengambilan keputusan penentuan waktu panen yang optimal agar hasil yang diperoleh dapat memenuhi ketentuan dalam Permen No.1/2015. Alasan penggunaan SEM PLS dalam penelitian ini adalah karena PLS merupakan metode analisis yang powerfull dan sering disebut juga sebagai soft modeling karena meniadakan asumsi-asumsi OLS (Ordinary Least Square) (Monecke dan Leisch, 2012).

SEM PLS biasanya terdiri dari dua sub model, yaitu model pengukuran (measurement model) atau outer model dan model struktural (structural model) atau inner model. Model pengukuran menunjukkan bagaimana variabel manifest atau observed variabel merepresentasi variabel laten untuk diukur. Sedangkan model struktural menunjukkan kekuatan estimasi antar variabel laten atau konstruk. Evaluasi terhadap model SEM PLS yang dibangun dalam mengevaluasi outer model dan mengevaluasi inner model menggunakan perangkat lunak SMART PLS dengan menggunakan data primer yang berasal dari data 96 responden dengan perincian pelaku usaha pembesaran lobster pasir sebanyak 73 orang dan pelaku usaha pembesaran lobster mutiara sebanyak 33 orang.

Model SEM PLS yang digunakan dikembangkan dalam penelitian ini adalah pengembangan dari model yang dibuat oleh Reay (1979) dimana intelektualitas pelaku usaha pembesaran lobster adalah penyokong keberhasilan usaha budidaya. Dalam hal ini, intelektual menjadi faktor pembeda dari setiap kegiatan usaha karena modal intelektual memengaruhi pengetahuan dan perilaku individu melebihi nilai aktiva berwujud dari suatu usaha. Model yang dibangun dikembangkan dari Suroso dan Siahaan (2006); Sen dan Walle (2014) yang pada awalnya dibuat untuk meneliti tekanan dalam pengambilan keputusan di lingkungan kerja dengan menggunakan model tripatrit (Petty dan Guthrie, 2000) berupa modal intelektual yang terdiri dari dari modal internal, modal eksternal, dan modal manusia (human capital). Agar sesuaikan dengan kondisi yang terjadi pada usaha pembesaran lobster, dilakukan modifikasi dengan melakukan penambahan variabel eksogen berupa gender pada aspek Modal Internal (internal capital). Kedua, penambahan variabel endogen berupa hubungan patron-klien, Ketiga, mengganti variabel decision-making performance dengan keputusan waktu panen yang mengacu pada ketidakpastian usaha perikanan (business uncertainty in fishery systems). Modifikasi dari model Sen dan Walle (2014) dilakukan dengan pertimbangan sebagai berikut:

\section{Penambahan variabel eksogen berupa gender (X1.6) pada modal internal (internal capital).}

Penambahan variabel gender ini didasari untuk memahami dimensi sosial ekonomi kegiatan di sektor perikanan harus memahami secara mendetail faktorfaktor input berupa gender. Penambahan variabel gender didasari bahwa gender memiliki peran penting 
dalam kegiatan usaha rumah tangga pada keluarga pesisir di Indonesia. Kondisi ini sejalan dengan Kusnadi (2001) bahwa dampak dari sistem pembagian kerja keluarga pesisir adalah kaum perempuan mendominasi dalam urusan ekonomi rumah tangga dan pengambilan keputusan penting di rumah tangganya.

2. Penambahan variabel berupa hubungan patronklien (X6) yang akan memengaruhi pengambilan keputusan waktu panen.

Scott (1981); Eisenstadt dan Roniger (1984); dan Kusnadi (2001) bahwa pada masyarakat pesisir terdapat hubungan patron klien sangat memengaruhi pengambilan keputusan individu. Variabel yang memengaruhi hubungan patron klien dalam penelitian ini dibuat berdasarkan model yang dikembangkan oleh Scott (1981) dimana hubungan patron klien akan ditentukan oleh bentuk kepemilikan sumber daya (X6.1), hubungan resiprositas (X6.2), loyalitas (X6.3), dan bentuk hubungan personal (X6.4).

3. Mengganti variabel decision-making performance (Sen dan Walle 2014) dengan keputusan waktu panen.

Variabel keputusan waktu panen mengacu pada Charles (1998) dan Charles (2001) mengenai ketidakpastian usaha perikanan (business uncertainty in fishery systems) dengan menggunakan beberapa unsur ketidakpastian yang dianggap relevan dengan keputusan penentuan waktu panen dengan variabel berupa variabel ketidakpastian dari sumber daya alam yang terdiri tingkat kematian alami dari benih (natural mortality) (X7.1) dan keragaman benih (spatial heterogenety) (X7.2). Dan variabel dari variabel ketidakpastian dari sumber daya manusia, yaitu harga dan struktur pasar lobster (X7.3), perubahan teknologi (X7.4), dan respon pembudidaya atas perubahan aturan panen lobster (X7.5).

Sehingga hipotesis dalam penelitian ini adalah modal intelektual dari para pelaku usaha pembesaran lobster berupa modal internal, modal manusia, dan modal eksternal yang dipengaruhi oleh pengetahuan dan perilaku individu akan menjadi penentu dalam pengambilan keputusan waktu panen yang optimal dalam mengantisipasi aturan hukum yang belaku dalam Permen No.1/2015 dalam mengatasi masalah akibat adanya faktor-faktor berupa keterbatasan waktu, kompleksitas pekerjaan, dan hubungan patron-klien dalam penentuan waktu panen yang optimal. Ruang lingkup penelitian ini akan dibatasi kepada para pelaku usaha pembesaran lobster di Pulau Lombok yang paling tidak pernah satu kali melakukan panen lobster sesuai dengan ketentuan Permen No.1/2015 dengan species Lobster Pasir (Panulirus polyphagus), dan Lobster Mutiara (Panulirusornatus) dengan tidak membatasi jumlah lokasi pembesaran lobster yang dimiliki maupun status kepemilikan secara hukum.

\section{HASIL}

\section{Kegiatan Usaha Pembesaran Lobster}

Usaha pembesaran lobster di Pulau Lombok berbeda dengan usaha lobster di daerah lain karena lobster yang dijual tidak diambil di alam, hanya menur yang diambil dari alam dengan menggunakan alat yang bernama pocong. Namun, kondisi masyarakat rekatif masih sama dengan kondisi masyarakat pesisir di Indonesia lainya sebagaimana dikemukan oleh Prihandoko (2011) dan Fargomeli (2014). Menur ini kemudian dibesarkan dalam keramba jaring apung. Pada awalnya usaha pembesaran lobster adalah produk sampingan dari budidaya ikan kerapu dan rumput laut yang menggunakan rakit apung. Bagi masayarakat di Pulau Lombok, usaha pembesaran lobster ini tidak lagi menjadi usaha sampingan namun telah menjadi kegiatan utama sejak tahun 2000.

Di Pulau Lombok, terdapat dua spesies utama lobster yang dibudidayakan, yaitu lobster pasir (Panulirus homarus) dan lobster mutiara (Panulirusornatus). Biasanya pelaku usaha lobster menebar benih lobster Lobster Pasir dan Lobster Mutiara dengan perbandingan 3:1. Harga Panulirusornatus lebih rendah dari seharusnya karena ukuran panen relatif kecil $(<500$ gram). Sebaliknya, Panulirus homarus berukuran panen 200 gram hingga 300 gram.

Dari 96 responden, jumlah reponden yang melakukan pembesaran lobster pasir dan lobster mutiara sebanyak 10 responden. Secara keseluruhan jumlah jumlah pelaku usaha pembesaran lobster mutiara adalah 33 responden sedangkan lobster pasir sebanyak 73 responden. Lobster diberi pakan ikan rucah (trash fish) yang merupakan produk sampingan kegiatan penangkapan ikan normal. Ikan dirajang kasar dan diberikan setiap pagi dalam keadaan segar kepada lobster setelah penyortiran ikan tangkapan. Biasanya, ikan rucah 
hampir seluruhnya berupa spesies ikan kecil dengan sedikit spesies moluska dan krustasea. Penggunaan ikan rucah sebagai pakan utama sebenarnya memiliki dampak negatif terhadap laju pertumbuhan dan warna kulit lobster yang dihasilkan.

Di Desa Jerowaru dan Desa Paremas, keramba terbuat dari jaring ikan sintetis dengan ukuran kerapatan hingga $15 \mathrm{~mm}$, berbentuk kotak dengan ukuran $27 \mathrm{~m}^{3}(3 \mathrm{~m}$ x $3 \mathrm{~m}$ x $3 \mathrm{~m}$ ) yang ditambatkankan pada rangka apung yang terpasang pada pelampung berupa drum plastik atau besi. Spesifikasi keramba dan metode budidaya tersebut adalah sederhana tetapi efektif dan sesungguhnya sama dengan budidaya lobster yang dilakukan di Vietnam tempat industri akuakultur lobster telah berkembang dengan sangat berhasil.

Pada awal berlakunya Permen No.1/2015 hampir $70 \%$ kegiatan usaha pembesaran lobster dihentikan dan sebagian besar pelaku usaha lobster pada saat itu menganggur atau beralih profesi menjadi TKI. Hal ini dikarenakan dismaping ketiadaan menur, juga diakibatkan karena usaha pembesaran lobster menjadi tidak ekonomis lagi karena dengan metode produksi yang dilakukan di Pulau Lombok untuk peningkatan berat 100 gram membutuhkan waktu pembesaran kurang lebih satu tahun. Pada tahun 2016, para pelaku usaha pembesaran lobster menyiasati Permen No.1/2015 di Desa Jerowaru dan Desa Paremas telah membatasi waktu tunggu pembesaran menjadi paling lama 6 bulan dengan menggunakan menur dengan ukuran yang lebih besar. Dan apabila waktu pembesaran telah melewati enam bulan namun belum mencapai ukuran sesuai Permen No.1/2015, pelaku usaha pembesaran tersebut tetap akan menjualnya kepada patron. Atas lobster ini oleh Patron biasanya berupaya membesarkannya selama satu bulan atau menjual lobster tersebut sebagai bibit kepada pelaku usaha pembesaran lainnya.

Penggunaan lobster yang lebih besar tersebut selain mengurangi waktu tunggu juga dapat menghindari tingginya tingkat kematian lobster yang bisa mencapai 20-40\%. Dengan metode ini, di Desa Jerowaru dan Desa Paremas tingkat kematian lobster hanya berkisar $1 \%$. Ancaman terbesar bagi usaha pembesaran lobster justru diakibatkan oleh pencurian lobster pada malam hari sehingga alokasi waktu kerja yang diluangkan oleh para pelaku usaha pembesaran lobster justru dilakukan untuk kegiatan yang secara langsung tidak berimbas pada usaha untuk membesarkan lobster itu sendiri.
Dengan data jumlah keramba yang ada maka sebenarnya dapat dihitung jumlah dari lobster mutiara dan pasiryang dapat dihasilkan. Kapasitas keramba yang tersedia untuk lobster mutiara adalah 119 petak $\left(3.213 \mathrm{~m}^{3}\right)$ dan lobster pasir 395 petak $\left(10.665 \mathrm{~m}^{3}\right)$ yang dapat menampung masing-masing untuk lobster mutiara sebanyak 64.260 ekor dan lobster pasir sebanyak 213.300 ekor. Dengan kondisi ini apabila pelaku usaha pembesaran lobster mengikuti ketentuan Permen No.1/2015 maka potensi yang dapat dipanen untuk lobster mutiara adalah 12.852 $\mathrm{kg}$ dan lobster pasir $42.660 \mathrm{~kg}$. Namun, kenyataannya potensi yang ada tersebut di atas sulit untuk dicapai, hal ini dibuktikan dengan hasil produksi lobster yang dihasilkan untuk lobster mutiara sebanyak $2.368 \mathrm{~kg}$ dan lobster pasir sebanyak $6.989 \mathrm{~kg}$. Rata-rata feed conversion ratio (FCR) untuk lobster pasir sebesar 1:28 dan lobster mutiara sebesar 1:18 dengan waktu tunggu masing 210 hari dan 159 hari dengan berat rata-rata saat panen 185 gram dan 197 gram. Yang sebenarnya jika dibandingkan dengan Vietnam maka usaha pembesaran lobster di Pulau Lombok belum efisien karena di Vietnam dengan rata-rata FCR antara 1:31,8 sampai dengan 1: 30 untuk lobster pasir dengan waktu tunggu 18 bulan dengan berat lebih dari $1 \mathrm{~kg}$ per ekor dan untuk lobster mutiara dengan waktu tunggu 18 bulan dengan berat berkisar 350-400 gram (Ly, 2009).

Tingkat kepatuhan pelaku usaha lobster untuk mentaati Permen No.1/2015 cukup rendah (Tabel 2). Data menunjukkan bahwa usaha pembesaran lobster pasir dari 73 pelaku usaha hanya 23 pelaku usaha yang melakukan panen sesuai dengan Permen No.1/2015. Sedangkan dari usaha pembesaran lobster pasir hanya 16 dari 33 pelaku usaha saja yang mematuhi ketentuan Permen No.1/2015. Kondisi ini menunjukkan bahwa Permen No.1/2015 tidak dapat menjadi aturan (hukum) yang berfungsi sebagai alat perubahan sosial (law as social engineering) (Pound, 1921).

\section{Keragaan Pelaku Usaha Pembesaran Lobster}

Jumlah responden adalah 96 orang dari awalnya 97 orang. Responden dari Desa Jerowaru 46 orang dengan komposisi 36 pria dan 10 wanita. Sedangkan responden dari Desa Paremas 50 orang dengan komposisi 49 pria dan 1 wanita. Jumlah anggota keluarga responden adalah yang paling banyak 8 orang dan paling sedikit satu orang dengan rata-rata jumlah anggota keluarga 3 orang. Berdasarkan kelompok umur, responden termuda berumur 19 tahun sedangkan tertua berumur 70 tahun dengan rata-rata usia 43 tahun. Lama pengalaman 
melakukan usaha pembesaran lobster adalah yang tersingkat 1 tahun dan yang terlama 25 tahun dengan rata-rata pengalaman 5,6 tahun.

Pelaku usaha pembesaran lobster memiliki tingkat pendidikan yang rendah. Terdapat 20 orang responden yang tidak pernah mengikuti pendidikan formal. 6 responden tidak tamat sekolah dasar. 47 responden tamat sekolah dasar. Untuk responden dengan pendidikan menengah hanya berjumlah 23 orang dengan hanya 1 responden wanita dengan tamat dari SMP dan 6 responden pria yang lulus dari SMA. Dengan melakukan analisis dari data yang ada di Pulau Lombok pengetahuan dalam usaha pembesaran lobster diperoleh dari keluarga, hal ini dibuktikan dengan tingginya partisipasi anak-anak dalam usaha pembesaran lobster dalam alokasi waktu kerja keluarga.

Kondisi di Pulau Lombok berbeda dengan Sen dan Walle (2014) yang membentuk modal internal adalah pendidikan yang diperoleh di sekolah. Namun demikian, ketidaksesuaian ini dapat dijelaskan oleh Davies (2002) bahwa dalam konteks pendidikan, sekolah secara tradisional memberikan modal intelektual (intellectual capital) sedangkan keluarga memberikan modal sosial (social capital). Sehingga dalam hal ini modal sosial berperan dalam membentuk keahlian dalam usaha pembesaran lobster di Pulau Lombok. Namun, tingkat partisipasi anak-anak dari para pelaku usaha pembesaran lobster sudah semakin tinggi seiring dengan adanya program wajib belajar 9 tahun sebagaimana diamanatkan oleh Peraturan Pemerintah Nomor 47 Tahun 2008 Tentang Pelaksanaan Wajib Belajar 9 Tahun di tahun 2014 jumlah anak usia sekolah 7-15 tahun yang tidak bersekolah di Desa Jerowaru hanya 41 orang $(1,72 \%)$ dan Desa Paremas hanya 1 orang $(0,23 \%)$.

\section{Analisis SEM PLS}

Untuk melakuan analisis pengambilan keputusan waktu panen oleh pelaku usaha pembesaran lobster terlebih dahulu akan dilakukan pengujian terhadap data primer yang ada. Data primer yang diperoleh berdasarkan jawaban dari responden atas setiap pertanyaan dalam bentuk kuesioner terlebih dahulu akan dilakukan analisis deskriptif, melakukan transformasi data dari skala ordinal ke skala interval, melakukan pengujian model, dan melakukan pengujian hipotesis.

Analisis pengambilan keputusan waktu panen oleh pelaku usaha pembesaran lobster dengan menggunakan SEM PLS untuk merumuskan strategi pengambilan keputusan penentuan waktu panen yang efisien agar hasil yang diperoleh dapat memenuhi ketentuan dalam Permen No.1/2015. Alasan penggunaan SEM PLS adalah PLS merupakan metode analisis yang powerfull dan sering disebut juga sebagai soft modeling karena meniadakan asumsi-asumsi OLS seperti regresi. SEMPLS biasanya terdiri dari dua sub model, yaitu model pengukuran (measurement model) atau outer model dan model struktural (structural model) atau inner model. Model pengukuran menunjukkan bagaimana variabel manifest atau observed variabel merepresentasi variabel laten untuk diukur. Sedangkan model struktural menunjukkan kekuatan estimasi antar variabel laten atau konstruk. Evaluasi terhadap model SEM PLS yang dibangun dalam mengevaluasi outer model dan mengevaluasi inner model menggunakan perangkat lunak SMART PLS berasal dari data 96 responden dengan responden yang melakukan usaha pembesaran lobster pasir sebanyak 73 orang dan responden yang melakukan usaha pembesaran lobster mutiara sebanyak 33 orang.

Tabel 2. Data FCR, Berat, Waktu Tunggu, dan Kepatuhan Permen No.1/2015 dari Pelaku Usaha Pembesaran Lobster Jenis Pasir dan Mutiara

\begin{tabular}{lcccccccc}
\hline \multirow{2}{*}{ Uraian } & \multicolumn{2}{c}{ FCR } & \multicolumn{2}{c}{ Berat panen (gram) } & \multicolumn{2}{c}{ Waktu panen (hari) } & \multicolumn{2}{c}{ Permen No.1/2015 } \\
\cline { 2 - 8 } & Pasir & Mutiara & Pasir & Mutiara & Pasir & Mutiara & Pasir & Mutiara \\
\hline Minimal & $1: 16$ & $1: 11$ & 150 & 150 & 104 & 99 & & \\
Maksimal & $1: 41$ & $1: 23$ & 290 & 245 & 328 & 214 & & \\
Rata-rata & $1: 28$ & $1: 18$ & 185 & 197 & 210 & 159 & & \\
Modus & $1: 27$ & $1: 18$ & 160 & 175 & 104 & 175 & & 23 \\
Patuh & & & & & & & 50 & 17 \\
Tidak Patuh & & & & & & & & \\
\hline
\end{tabular}


Tabel 4. Keragaan responden

\begin{tabular}{lcc}
\hline \multicolumn{1}{c}{ Keragaan responden } & Pria & Wanita \\
\hline Kelompok Usia & & \\
Usia di bawah 30 tahun & 18 & 1 \\
Usia 31-40 tahun & 28 & 5 \\
Usia 41-49 tahun & 16 & \\
Usia 50-70 tahun & 16 & 6 \\
Pendidikan & & \\
Tidak sekolah & 16 & 4 \\
Tidak tamat SD & 5 & 1 \\
Tamat SD & 41 & 6 \\
Tamat SMP & 16 & 1 \\
Tamat SMA & 6 & \\
\hline
\end{tabular}

Evaluasi model pengukuran pada penelitian ini menggunakan 17 indikator yang merefleksikan ketiga variabel laten endogen (modal internal, modal manusia, dan modal eksternal), dan menggunakan 11 indikator yang merefleksikan ketiga variabel laten eksogen (keterbatasan waktu, kompleksitas pekerjaan, dan hubungan patron-klien). Dalam penyusunan model SEM PLS, apabila terdapat indikator yang memiliki nilai loading factor $<0.5$, harus dilakukan calculating kembali terhadap model awal sehingga menghasilkan loading factor seluruh indikator reflektif bernilai $>0.5$ sebagai kriteria dari uji validitas convergent konstruk laten (Ghozali, 2006).

Setelah dilakukan beberapa iterasi, diperoleh model akhir pada Gambar 2 yang menunjukan semua indikator telah memiliki nilai loading factor $>0.5$. Indikator modal internal (X1) dalam pengaruhnya terhadap keterbatasan waktu (X4), kompleksitas pekerjaan (X5), hubungan patron-klien (X6) masing-masing sebesar 0,$474 ; 0,365 ; 0,407$ dengan direfleksikan oleh proses dan filosofi manajemen usaha (X1.1) sebesar 0.733, akses informasi (X1.3) sebesar 0,698, hak atas kekayaan intelektual (X1.4) sebesar 0,851, dan penelitian dan pengembangan (X1.5) sebesar 0,777. Indikator modal manusia (X2) dalam pengaruhnya terhadap keterbatasan waktu (X4), kompleksitas pekerjaan (X5), hubungan patron-klien (X6) masing-masing sebesar 0,221; 0,319; 0,057 dengan direfleksikan oleh pengetahuan individual (X2.1) sebesar 0,745, keragaman pengetahuan (X2.3) sebesar 0,675 , pendidikan dan pelatihan (X2.4) sebesar 0,651 , dan pembelajaran (X2.5) sebesar 0,809. Indikator modal eksternal (X3) dalam pengaruhnya terhadap keterbatasan waktu (X4), kompleksitas pekerjaan (X5), hubungan patron-klien (X6) masing-masing sebesar 0,$050 ; 0,014 ; 0,338$ dengan direfleksikan oleh kerja sama (X3.1) sebesar 0,846, hubungan dengan komunitas (X3.3) sebesar 0,682, dan hubungan dengan keuangan usaha (X3.6) sebesar 0,679.

Berdasarkan model akhir pada Gambar 2 hubungan antar indikator terhadap keputusan waktu panen (X7) adalah sebagai berikut, pertama, indikator keterbatasan waktu (X4) memengaruhi keputusan waktu panen (X7) sebesar 0,217 dengan direfleksikan oleh ketergesaan (X4.1) sebesar 0,672, situasi ketidakpastian (X4.2) sebesar 0,730 , waktu pengambilan keputusan yang pendek (X4.4) sebesar 0,837. Kedua, indikator kompleksitas pekerjaan (X5) memengaruhi keputusan waktu panen (X7) sebesar 0,146 dengan direfleksikan oleh pekerjaan yang tidak pasti (X5.1) sebesar 0,779, adanya pekerjaan yang tidak diperkirakan sebelumnya (X5.2) sebesar 0,792. Ketiga, hubungan patron-klien (X6) memengaruhi keputusan waktu panen (X7) sebesar 0,474 dengan direfleksikan oleh kepemilikan sumber daya (X6.1) sebesar 0,751, hubungan resiprositas (X6.2) sebesar 0,775, loyalitas (X6.3) sebesar 0,751, hubungan personal (X6.4) sebesar 0,821. Selanjutnya, variabel keputusan waktu panen (X7) terdapat empat variabel reflektif, yaitu tingkat kematian alami (natural mortality) (X7.1) sebesar 0,608, keragaman benih (spatial heterogenety) (X7.2) sebesar 0,615, harga dan struktur pasar lobster (X7.3) sebesar 0,915, perubahan teknologi (X7.4) sebesar 0,800.

SEM PLS melakukan pengujian kedua untuk validitas convergent, yaitu dengan melihat nilai Average Variance Extraxted (AVE) pada model indikator reflektif. Kriteria model memiliki validitas yang baik adalah apabila masing-masing variabel laten dengan indikator reflektif memiliki AVE di atas 0,5. Hasil analisis yang terlihat pada Tabel 5, nilai AVE dari masing-masing variabel laten memiliki nilai $>0,5$ sehingga dapat dikatakan bahwa model PLS memenuhi syarat validitas convergent yang baik.

Pengukuran selanjutnya, yaitu pengujian reliabilitas terhadap model yang digunakan untuk membuktikan keakuratan, konsistensi, dan ketepatan instrumen dalam mengukur konstruk. Uji reliabilitas dengan mengukur composite reliability terhadap variabel laten yang memiliki nilai lebih dari 0,6 dikatakan reliabel. Hasil penelitian berdasarkan Tabel 5, menunjukkan semua konstruk laten memiliki reliabilitas yang baik, akurat dan konsisten karena memenuhi syarat dengan nilai composite reliability pada setiap konstruk laten lebih dari 0,6 . Pengujian validitas discriminant dilakukan dengan 
prinsip bahwa pengukur-pengukur (manifest variabel) konstruk yang berbeda seharusnya tidak berkolerasi tinggi (Ghozali, 2008). Tabel 6 menunjukkan bahwa nilai korelasi antar konstruk secara keseluruhan telah kurang dari nilai $\sqrt{ }$ AVE dapat dikatakan bahwa model telah memenuhi syarat validitas discriminant.

\section{Evaluasi Model Struktural}

Pengukuran inner model dengan cara bootstrapping pada outer model akhir dengan melihat nilai T-statistik untuk menilai untuk menguji hipotesis pada setiap jalur dari variabel eksogen ke variabel endogen. Hasil bootstrapping pada Tabel 3 menunjukkan sembilan jalur memiliki pengaruh yang signifikan ( $\mathrm{t}$-statistik $>\mathrm{t}$-tabel 1,96 pada taraf nyata $5 \%$ ), sedangkan tiga jalur lain tidak berpengaruh nyata. Modal internal berpengaruh signifikan terhadap keterbatasan waktu dengan nilai t statistik sebesar 6,24. Modal manusia berpengaruh signifikan tergadap keterbatasan waktu dengan nilai t statistik sebesar 3,60. Modal internal berpengaruh terhadap kompleksitas pekerjaan dengan nilai t statistik sebesar 4,52. Modal manusia berpengaruh terhadap kompleksitas pekerjaan dengna nilai t statistik sebesar 4,92. Modal internal berpengaruh secara signifikan terhadap hubungan patro-klien dengan nilai $t$ statistik sebesar 5,38. Modal eksternal berpengaruh secara signifikan terhadap hubungan patro-klien dengan nilai t statistik sebesar 5,93. Keterbatasan waktu berpengaruh secara signifikan terhadap keputusan waktu panen dengan nilai $\mathrm{t}$ statistik sebesar 3,83. Kompleksitas pekerjan berpengaruh secara signifikan terhadap keputusan waktu panen dengan nilai t statistik sebesar 2,39. Hubungan patron-klien berpengaruh secara signifikan terhadap keputusan waktu panen dengan nilai t statistik sebesar 12.14 .

Tabel 4. Keragaan responden

\begin{tabular}{lcc}
\hline \multicolumn{1}{c}{ Variabel } & AVE & $\begin{array}{c}\text { Composite } \\
\text { Reliability }\end{array}$ \\
\hline Keputusan Waktu Panen & 0,53 & 0,81 \\
Keterbatasan Waktu & 0,52 & 0,76 \\
Kompleksitas Pekerjaan & 0,62 & 0,76 \\
Modal Eksternal & 0,55 & 0,78 \\
Modal Internal & 0,59 & 0,85 \\
Modal Manusia & 0,52 & 0,81 \\
Patron-Klien & 0,61 & 0,86 \\
\hline
\end{tabular}

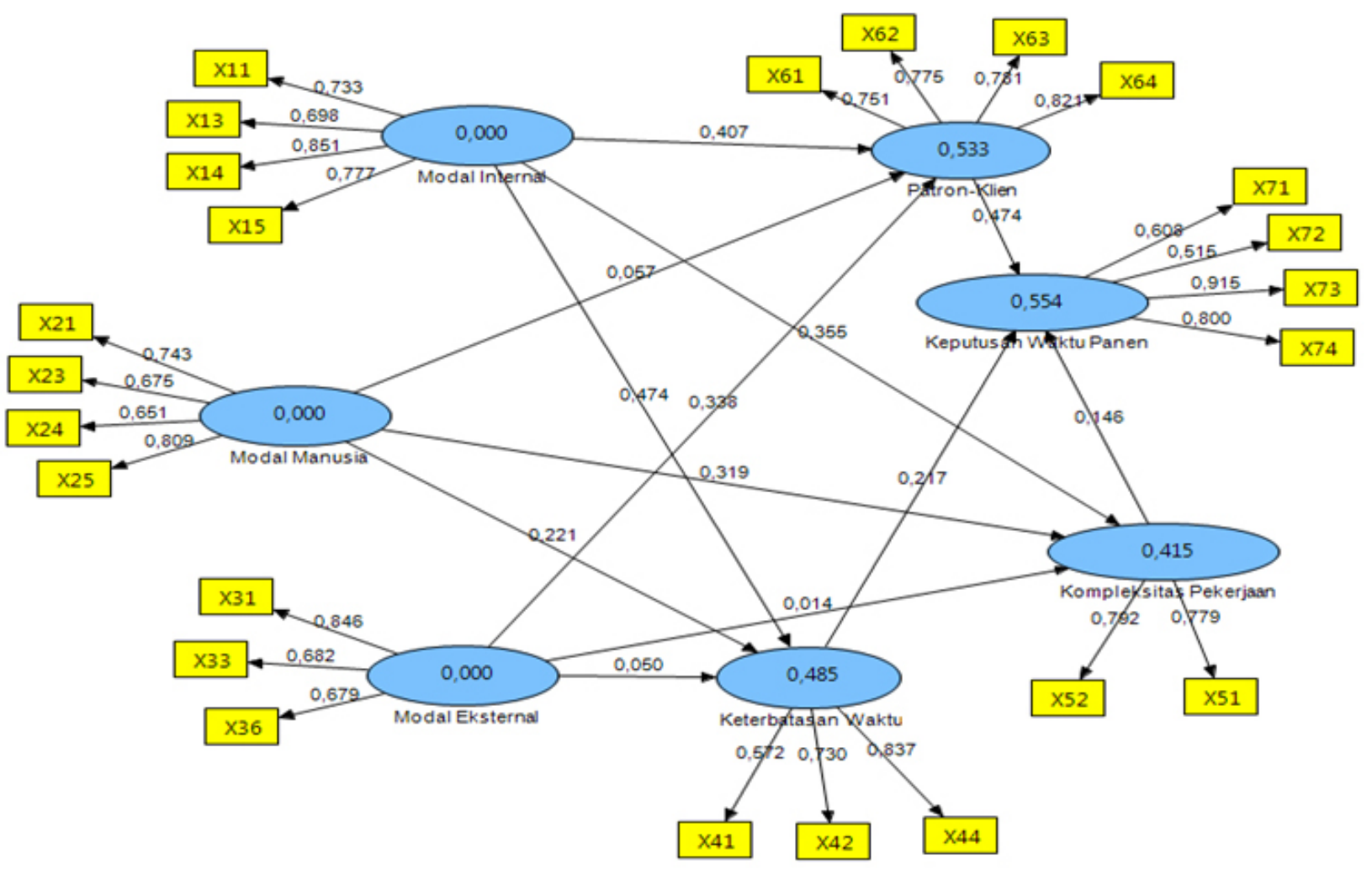

Gambar 2. Loading factor pada model pengukuran akhir 
Tabel 6. Matriks korelasi antara variabel laten

\begin{tabular}{|c|c|c|c|c|c|c|c|}
\hline Indikator & $\begin{array}{c}\text { Keputusan } \\
\text { Waktu Panen }\end{array}$ & $\begin{array}{c}\text { Keterbatasan } \\
\text { Waktu }\end{array}$ & $\begin{array}{l}\text { Kompleksi- } \\
\text { tas Pekerjaan }\end{array}$ & $\begin{array}{c}\text { Modal } \\
\text { Eksternal }\end{array}$ & $\begin{array}{l}\text { Modal } \\
\text { Internal }\end{array}$ & $\begin{array}{c}\text { Modal } \\
\text { Manusia }\end{array}$ & $\begin{array}{l}\text { Patron- } \\
\text { Klien }\end{array}$ \\
\hline $\begin{array}{l}\text { Keputusan } \\
\text { Waktu Panen }\end{array}$ & $\sqrt{ } \mathrm{AVE}=0,73$ & & & & & & \\
\hline $\begin{array}{l}\text { Keterbatasan } \\
\text { Waktu }\end{array}$ & 0,65 & $\sqrt{ } \mathrm{AVE}=0,72$ & & & & & \\
\hline $\begin{array}{l}\text { Kompleksitas } \\
\text { Pekerjaan }\end{array}$ & 0,63 & 0,68 & $\sqrt{ } \mathrm{AVE}=0,79$ & & & & \\
\hline Modal Eksternal & 0,66 & 0,53 & 0,53 & $\sqrt{ } \mathrm{AVE}=0,74$ & & & \\
\hline Modal Internal & 0,72 & 0,64 & 0,64 & 0,69 & $\sqrt{ } \mathrm{AVE}=0,77$ & & \\
\hline Modal Manusia & 0,60 & 0,59 & 0,70 & 0,65 & 0,77 & $\sqrt{ } \mathrm{AVE}=0,72$ & \\
\hline Patron-Klien & 0,69 & 0,68 & 0,57 & 0,65 & 0,67 & 0,59 & $\sqrt{\mathrm{AVE}}=0,78$ \\
\hline
\end{tabular}

Model struktural keterbatasan waktu menghasilkan nilai $\mathrm{R}$ square $58,76 \%$. Artinya, keterbatasan waktu mampu dijelaskan modal eksternal, modal internal, dan modal manusia sebesar 58,76\% sedangkan 41,24\% dijelaskan oleh faktor lainnya. Model struktural kompleksitas pekerjaan menghasilkan nilai $\mathrm{R}$ square $48,83 \%$ yang artinya kompleksitas pekerjaan dijelaskan modal eksternal, modal internal, dan modal manusia sebesar $48,83 \%$ sedangkan $51,17 \%$ dijelaskan oleh faktor lainnya. Model struktural hubungan patron-klien menghasilkan nilai R square 53,41\% artinya hubungan patron-klien mampu dijelaskan modal eksternal, modal internal, dan modal manusia sebesar $53,41 \%$ sedangkan $46,59 \%$ dijelaskan oleh faktor lain di luar model. Model struktural keputusan waktu panen menghasilkan nilai $\mathrm{R}$ square $58,76 \%$. Artinya, keputusan waktu panen mampu dijelaskan oleh model sebesar 58,76\%, sedangkan $41,24 \%$ dijelaskan oleh faktor lainnya.

Variabel modal internal dan variabel modal manusia memiliki pengaruh positif terhadap keterbatasan waktu masing-masing sebesar 0,47 dan 0,22. Modal internal yang semakin baik akan mengatasi masalah keterbatasan waktu dalam usaha pembesaran lobster yang direflektifkan dengan proses dan filosofi manajemen usaha yang dijalankan secara baik, semakin terbukanya akses informasi, kepemilikan hak atas kekayaan intelektual atas proses pembesaran lobster, dan aktif dalam melakukan kegiatan penelitian dan pengembangan terkait usaha pembesaran lobster. Demikian pula halnya dengan modal manusia yang semakinbaikakanmengatasimasalahketerbatasanwaktu dalam usaha pembesaran lobster yang direflektifkan dengan peningkatan pengetahuan individual, memiliki keragaman pengetahuan, semakin tingginya pendidikan dan seringnya mengikuti pelatihan, dan aktif dalam mengikuti pembelajaran baik sendiri ataupun secara berkelompok.
Demikian pula halnya dengan variabel modal internal dan variabel modal manusia memiliki pengaruh positif terhadap kompleksitas pekerjaan masing-masing sebesar 0,35 dan 0,32. Modal internal yang semakin baik akan mengatasi masalah kompleksitas pekerjaan yang dihadapi oleh pelaku usaha pembesaran lobster yang direflektifkan dengan proses danfilosofimanajemenusaha yang dijalankan secara baik, semakin terbukanya akses informasi, kepemilikan hak atas kekayaan intelektual atas proses pembesaran lobster, dan aktif dalam melakukan kegiatan penelitian dan pengembangan terkait usaha pembesaran lobster. Demikian pula halnya dengan modal manusia yang semakin baik akan mengatasi masalah keterbatasan waktu dalam usaha pembesaran lobster yang direflektifkan dengan peningkatan pengetahuan individual, memiliki keragaman pengetahuan, semakin tingginya pendidikan dan seringnya mengikuti pelatihan, dan aktif dalam mengikuti pembelajaran baik sendiri ataupun secara berkelompok.

Variabel modal internal dan variabel modal eksternal memiliki pengaruh positif terhadap hubungan patronklien masing-masing sebesar 0,41 dan 0,34. Modal internal yang semakin baik akan mengatasi masalah hubungan patron-klien yang dihadapi oleh pelaku usaha pembesaran lobster yang direflektifkan dengan proses dan filosofi manajemen usaha yang dijalankan secara baik, semakin terbukanya akses informasi, kepemilikan hak atas kekayaan intelektual atas proses pembesaran lobster, dan aktif dalam melakukan kegiatan penelitian dan pengembangan terkait usaha pembesaran lobster. Demikian pula halnya dengan modal eksternal yang semakin baik akan mengatasi masalah hubungan patronklien dalam usaha usaha pembesaran lobster yang direflektifkan dengan kemampuan dalam melakukan kerja sama, hubungan pelaku usaha pembesaran dengan komunitas, dan hubungan dalam mengatasi masalah keuangan usaha. 
Sebaliknya, variabel keterbatasan waktu terhadap keputusan penentuan sebesar 0,22. Keterbatasan waktu yang dihadapi oleh pelaku usaha pembesaran lobster untuk memenuhi kebutuhan hidupnya yang semakin besar akan mempercepat penentuan waktu panen yang direflektifkan dengan pengambilan keputusan yang tergesa-gesa sebesar 0,572, dihadapkan pada situasi ketidakpastian sebesar 0,730 , dan pengambilan keputusan yang dibatasi oleh waktu yang pendek sebesar 0,837 .

Sesuai dengan data hasil penelitian pada Tabel 7, variabel kompleksitas pekerjaan memiliki pengaruh positif terhadap keputusan waktu panen sebesar 0,15. Kompleksitas pekerjaan yang dihadapi oleh pelaku usaha pembesaran lobster akan mempercepat penentuan waktu panen yang direflektifkan dengan adanya pekerjaan yang tidak pasti sebesar 0,792 , dan terjadinya pekerjaan yang tidak diperkirakan sebelumnya sebesar 0,779 . Dalam hal ini variabel hubungan patron-klien memiliki pengaruh yang paling besar terhadap keputusan penentuan waktu panen sebesar 0,47. Hubungan patron-klien yang dihadapi oleh pelaku usaha pembesaran lobster yang akan mempercepat penentuan waktu panen yang direflektifkan dengan kepemilikan sumber daya sebesar 0,751 , hubungan resiprositas sebesar 0,775 , loyalitas sebesar 0,751 , hubungan personal sebesar 0,821 .

\section{Implikasi Manajerial}

Hasil penelitian menunjukkan bahwa penentuan keputusan waktu panen terutama sangat dipengaruhi oleh hubungan patron-klien. Bentuk hubungan patronklien yang ada secara spesifik ditentukan oleh adanya suatu personal antara pelaku usaha pembesaran lobster dengan patronnya. Bentuk hubungan patron-klien ini ternyata sudah pada tingkatan yang sangat erat dan ikatannya sudah tidak lagi bersifat luwes dan meluas (diffuse flexibility), hal ini dibuktikan dengan keberanian dari para pelaku usaha pembesaran lobster untuk lebih mematuhi keinginan patron dibandingkan dengan melaksanakan kepatuhan terhadap aturan hukum yang berlaku, dalam hal ini Permen No.1/2015.

Bentuk hubungan personal ini, secara ekonomi juga telah dapat merubah pola pikir manusia menjadi irasional karena dalam penelitian ini walaupun terjadi kenaikan ataupun penurunan harga lobster tidak menjadikan harga tersebut menjadi penentu dalam pengambilan keputusan, demikian pula halnya jika terjadi kesulitan akibat kompleksitas pekerjaan dan keterbatasan waktu yang dihadapi pelaku usaha pembesaran lobster maka kepentingan patron tidak dapat diabaikan sehingga mengalahkan kepentingan individu itu sendiri. Dengan demikian, kedudukan asimetri hubungan patron-klien mengacu pada Scoot (1972) hubungan patron-klien pada usaha pembesaran lobster di Indonesia sudah berada pada kondisi yang memposisikan patron sudah berada pada posisi dominatif dan eksploitatif yang ekstrim.

Implikasi manajerial yang dapat dilakukan adalah mengacu kepada konsep yang dikembangkan oleh Scoot (1972) atas hubungan yang tidak adil dan eksploitatif antara patron-klien diakhiri dengan ambang batas yang berdimensi kultural dan dimensi obyektif dengan memberdayakan potensi pada diri sendiri, keluarga dan kemampuan masyarakat yang ada. Hal ini dimungkinkan karena berdasarkan budaya masyarakat sebenarnya masyarakat di Pulau Lombok memiliki karekteristik sebagai wirausahawan yang tangguh walaupun tidak memiliki pendidikan formal yang tinggi dan memiliki kemampuan keuangan yang terbatas.

Tabel 7. Nilai loading factor dan t-statistik

\begin{tabular}{|c|c|c|c|}
\hline Variabel & Loading factor & T-statistik & R-square \\
\hline Modal eksternal $\rightarrow$ Keterbatasan waktu & 0,05 & 0,67 & \multirow{3}{*}{58,76} \\
\hline Modal internal $\rightarrow$ Keterbatasan waktu & 0,47 & 6,24 & \\
\hline Modal manusia $\rightarrow$ Keterbatasan waktu & 0,22 & 3,60 & \\
\hline Modal internal $\rightarrow$ Kompleksitas pekerjaan & 0,35 & 4,52 & \multirow{3}{*}{48,83} \\
\hline Modal manusia $\rightarrow$ Kompleksitas pekerjaan & 0,32 & 4,92 & \\
\hline Modal eksternal $\rightarrow$ Kompleksitas pekerjaan & 0,01 & 0,18 & \\
\hline Modal internal $\rightarrow$ Hubungan patron-klien & 0,41 & 5,38 & \multirow{3}{*}{53,41} \\
\hline Modal eksternal $\rightarrow$ Hubungan patron-klien & 0,34 & 5,93 & \\
\hline Modal manusia $\rightarrow$ Hubungan patron-klien & 0,06 & 0,83 & \\
\hline Keterbatasan waktu $\rightarrow$ Keputusan waktu panen & 0,22 & 3,83 & \multirow{2}{*}{58,76} \\
\hline Kompleksitas pekerjaan $\rightarrow$ Keputusan waktu panen & 0,15 & 2,39 & \\
\hline
\end{tabular}


Faktor berikutnya yang memengaruhi penentuan pangambilan keputusan waktu panen pada usaha pembesaran lobster adalah faktor keterbatasan waktu. Pengambilan keputusan waktu panen pada hakekatnya adalah suatu bentuk keputusan profesional dari pelaku usaha pembesaran lobster yang bertumpu pada suatu keputusan rasional. Dimana pengambilan keputusan yang rasional tersebut memiliki salah satu prasyarat, yaitu tersedia waktu yang cukup untuk menghindari adanya bias (Taylor, 2013). Tersedianya waktu yang cukup tersebut dimaksudkan untuk menentukan permasalahan riil yang ada, identifikasi dan analisis masalah, penyusunan alternatif dan solusi terbaik, serta analisis masalah potensial yang mungkin timbul. Ketersediaan waktu ini dalam usaha pembesaran lobster tidaklah mencukupi karena tidak adanya sumber alternatif bagi pemenuhan keuangan keluarga lainya sedangkan kebutuhan hidup sehari-hari harus segera dipenuhi.

Kondisi ini dapat dibuktikan bahwa keputusan waktu panen lobster ternyata hasilnya tidak dapat selamanya benar dalam hal tidak dapat merubah situasi menjadi lebih baik atau memberikan keuntungan seperti yang diharapkan, bahkan terdapat keputusan yang merugikan. Ini dibuktikan tingkat FCR yang tinggi dan panen lobster pada ukuran yang tidak sesuai dengan Permen No.1/2015. Namun demikian, keterbatasan waktu dalam pengambilan keputusan panen lobster sebenarnya dapat diatasi dengan memperbaiki pola produksi dengan pemberian pakan yang baik sehingga dapat mempermudah prediksi dari ukuran lobster yang dihasilkan dan mencari sumber alternatif sumber keuangan keluarga baru karena selama ini dalam proses pembesaran lobster seluruh waktu keluarga tercurah pada usaha pembesaran lobster walaupun diketahui kegiatan tersebut tidak berdampak pada pertumbuhan lobster itu sendiri.

Variabel terakhir yang memengaruhi pengambilan keputusan waktu panen lobster adalah kompleksitas pekerjaan yang dihadapi. Namun demikian, dengan melihat hasil pengolahan data yang ada sebenarnya komplesitas pekerjaan yang dihadapi oleh pelaku usaha pembesaran lobster adalah suatu bahaya laten yang harus segara diatasi. Masalah kompleksitas pekerjaan ini harus segera diatasi mengingat para pelaku usaha pembesaran lobster rata-rata memiliki tingkat pendidikan yang rendah dan masih menggunakan pola pembesaran secara tradisional.
Sebagaimana diketahui bahwa terdapat suatu keharusan untuk menggunakan teknologi untuk mengatasi masalah pakan dan rentang waktu produksi yang lama hanya dapat teratasi oleh adanya penggunaan teknologi yang baru. Dimana penggunaan teknologi pasti akan menyebabkan pekerjaan yang akan dilakukan akan semakin kompleks akan memiliki potensi untuk memengaruhi pengambilan keputusa waktu panen lobtser sehingga dibutuhkan adanya pelatihan untuk merubah pola produksi dan pola perilaku dari pelaku usaha pembesaran lobster. Hal ini harus dilakukan mengingat adanya nilai yang tinggi dari variabel yang diakibatkan oleh adanya pekerjaan yang tidak pasti dan adanya pekerjaan yang tidak diperkirakan sebelumnya.

\section{KESIMPULAN DAN SARAN}

\section{Kesimpulan}

Tingkat kepatuhan pelaku usaha pembesaran lobster melaksanakan Permen No.1/2015 masih rendah, yaitu lobster pasir 31,50\% dan lobster mutiara 48,48\% Tingkat kepatuhan pelaku usaha lobster untuk mentaati Permen No.1/2015 cukup rendah. Data menunjukkan bahwa untuk usaha pembesaran lobster pasir hanya 31,50\% yang mematuhi ketentuan dalam Permen No.1/2015. Sedangkan dari usaha pembesaran lobster pasir hanya 16 dari 33 pelaku usaha saja yang mematuhi ketentuan Permen No.1/2015. Dengan rata-rata berat lobster saat panen 185 gram dan 197 gram. FCR untuk lobster pasir 1:28 dan lobster mutiara 1:18 dengan waktu tunggu rata-rata 210 hari dan 159 hari.

Pengambilan keputusan dalam menentukan waktu panen lobster secara berturut-turut oleh hubungan patron-klien, keterbatasan waktu, dan kompleksitas pekerjaan yang dihadapi. Hubungan patron-klien yang terbentuk sudah bersifat personal yang mengalahkan kepentingan individu itu sendiri yang dibuktikan dengan ketidakpatuhan terhadap hukum formal yang berlaku dibandingkan dengan memenuhi keinginan dari patron. Keterbatasan waktu dalam pengambilan keputusan waktu panen membatasi pengambilan keputusan yang rasional karena pelaku usaha pembesaran lobster dihadapkan pada ketiadaan sumber alternatif bagi pemenuhan keuangan keluarga untuk memenuhi kebutuhan hidup sehari-hari. Kompleksitas pekerjaan yang dihadapi oleh pelaku usaha pembesaran 
lobster adalah suatu bahaya laten yang harus segara diatasi mengingat masalah rentang waktu pembesaran yang panjang hanya dapat diatasi dengan pengenalan teknologi baru yang pastinya menuntut adanya metode kerja baru disatu sisi yang dihadapkan pada pendidikan yang rendah dari pelaku usaha pembesaran lobster dan penggunaan pola pembesaran secara tradisional.

\section{Saran}

Untuk menghindari waktu tunggu yang terlalu lama maka dibutuhkan perubahan pola pikir (the shift paradigm) dengan menerapkan konsep ban berjalan pada proses pembesaran lobster dimana setiap pelaku usaha pembesaran lobster akan terbagi berdasarkan ukuran berat lobster yang dihasilkan dan akhirnya secara berurutan akan dihasilkan lobster dengan ukuran yang sesuai dengan ketentuan yang berlaku. Selanjutnya, hal harus menjadi perhatian dalam proses bisnis ini adalah jangan sampai pelaku usaha pembesaran lobster terkonsentrasi pada satu ukuran saja. Dalam hal ini, walaupun akan berakibat pada timbulnya interpedensi namun dengan adanya spesialisasi ini maka sinergi antar pelaku usaha dapat dibangun.

Mengingat pendidikan dari pelaku usaha pembesaran lobster masih didominasi oleh tingkat pendidikan yang rendah maka kebijakan selain memiliki keharusan untuk memahami konteks pengelolaan sumber daya perikanan secara holistik, mencegah kegagalan pasar, dan misalokasi sumber daya. Harus pula membentuk aturan yang dapat dijadikan alat perubahan sosial (law as social engineering). Hal tersebut di atas harus dilakukan mengingat posisi nelayan, pembudidaya perikanan, dan masyarakat pesisir pada umumnya, jika ada perubahan aturan akan mengalami kesulitan untuk melakukan likuidasi atau merubah bentuk atas aset-aset yang dimilikinya akibat dari kekakuan aset perikanan (fixity and rigidity of assets).

Untuk mengurangi ketergantungan kepada patron, maka hubungan patron-klien harus diatasi memberdayakan potensi pada diri sendiri, keluarga dan kemampuan masyarakat yang ada. Demikian pula halnya dengan keterbatasan waktu dalam pengambilan keputusan panen lobster diatasi dengan memperbaiki pola produksi dengan pemberian pakan untuk mempermudah prediksi dari ukuran lobster yang dihasilkan dan berupaya mencari sumber alternatif sumber keuangan keluarga. Masalah kompleksitas pekerjaan akibat dari introduksi teknologi harus diatasi secara serius mengingat para pelaku usaha pembesaran lobster rata-rata memiliki tingkat pendidikan yang rendah dan masih menggunakan pola pembesaran secara tradisional, hal ini dilakukan dengan melakukan pelatihan untuk merubah pola produksi dan pola perilaku dari pelaku usaha pembesaran lobster.

Bagi penelitian selanjutnya, model pengambilan keputusan perlu dikembangkan dengan menambahkan variabel lain berdasarkan teori-teori yang ada yang diduga dapat memengaruhi meningkatnya ketepatan dalam menentukan waktu panen yang optimal. Terkait dengan teknis kebutuhan analisis data maka perlu juga ditambahkan jumlah responden yang berasal dari beberapa lokasi penelitian yang berbeda. Dengan semakin besar dan luas respondennya maka hasil yang diperoleh akan semakin tinggi tingkat keakurasian dari hasil penelitian yang digeneralisasikan kepada seluruh anggota populasi.

\section{DAFTAR PUSTAKA}

Acheson J, Reidman R. 1982. Biological and economic effects of increasing the minimum legal size of American Lobster in Maine. Transactions of The American Fisheries Society 111(1):1-12.https://doi.org/10.1577/15488659(1982) $111<1$ : BAEEOI $>2.0 . C O ; 2$.

Charles AT. 1998. Living with uncertainty in fisheries: analytical methods, management priorities and the Canadian ground fishery experience. Fisheries Research 37:37-50. https://doi. org/10.1016/S0165-7836(98)00125-8.

Charles AT. 2001. Sustainable Fishery Systems. Oxford: Blackwell Science Ltd.

Hilborn R. 2007. Managing fisheries is managing people: what has beenlearned? Fish and Fishries 8:285-296.https://doi.org/10.1111/j.14672979.2007.00263_2.x.

Junaidi M, Cokrowati N, Abidin Z. 2010. Aspek reproduksi lobster (Panulirus sp.) di Perairan Teluk Ekas Pulau Lombok. Jurnal Kelautan 3(1):29-35.

Kementerian Kelautan dan Perikanan. 2015. Laporan Kinerja Kementerian Kelautan dan Perikanan Tahun 2014. Jakarta: Kementerian Kelautan dan Perikanan.

Kusnadi. 2001. Nelayan: Strategi Adaptasi dan Jaringan Sosial. Bandung: HUP.

Petersen EH, Jones C, Priyambodo B. 2012. 
Bioeconomics of spiny lobster farming in Indonesia. Asian Journal of Agriculture and Development 10 (1):25-39.

Petty R, Guthrie J. 2000. Intellectual capital literature review:measurement, reporting and management. Journal of Intellectual Capital 1(2):155-176. https://doi.org/10.1108/14691930010348731.

Pound R. 1921. The Spirit of Common Law. Francestown: Marshall Jones Company.

Prihandoko. 2011. Faktor-faktor yang memengaruhi perilaku nelayan artisanal dalam pemanfaatan sumberdaya perikanan di Pantai Utara provinsi Jawa Barat. Makara Sosial Humaniora 15(2):117-126.

Reay PJ. 1979. Aquaculture. London: Arnold.

Scott JC. 1981. Moral Ekonomi Petani: Pergolakan dan Subsistensi di Asia Tenggara. Basari H, penerjemah. Jakarta: LP3ES. Terjemahan dari: The Moral Economy of the Peasant: Rebellion and Subsistence in Southeast Asia.

Sen Z, Walle BVd. 2014. How intellectual capital reduces stress on organizational decisionmaking performance: the mediating roles of task complexity and time pressure. Proceedings of the 11th International ISCRAM Conference; 2014 May; Pennsylvania, Amerika Serikat. Pennsylvania: University Park.

Simon HA. 1959. Theories of decision-making in economics and behavioral science. The American Economic Review 49(3):253-283.

Sundelof A, Grimm V, Ulmestrand M, Fiksen O. 2014. Modelling harvesting strategies for lobster fishery in northern Europe: the improtance of protecting egg-bearing females. Population Ecology 57:237-251. https://doi.org/10.1007/ s10144-014-0460-3.

Suroso AI, Siahaan R. 2006. Pengaruh stres dalam pekerjaan terhadap kinerja karyawan: studi kasus di perusahaan agribisnis PT NIC. Jurnal Manajemen \& Agribisnis 3(1):19-30.

Taylor MP. 2013. Bias and brains: Risk aversion and cognitive ability across real and hypothetical settings. Journal Risk Uncertainty 46:299-320. https://doi.org/10.1007/s11166-013-9166-8.

William J, Malcolm B. 2012. Farmer decision about selling wheat and managing wheat price risk in Australia. Australian Agribusiness Review 20:1-10. 